\title{
NOTES ON THE ANOMALURIDS OF RIO MUNI AND ADJACENT AREAS
}

\author{
Clyde Jones
}

\begin{abstract}
Information obtained from specimens collected and observed in Rio Muni and adjacent areas is presented for three species of anomalurids. Data available on distribution, habitat, and habits are summarized and discussed with regard to the ecological relationships of three species.
\end{abstract}

Little information has been published on distributions, habitats, and habits of most members of the Anomaluridae. General remarks on these rodents were presented by McLaughlin (1967) and Walker et al. (1968). Information available on the anomalurids known from West Africa was summarized by Rosevear (1969). Accounts and anecdotes of experiences with these mammals in Cameroon, Rio Muni, and adjacent areas were presented by Bates (1905), Sanderson (1940), Durrell (1954), Rahm (1969), and Adam et al. (1970). Anomalurids were included in the faunas of Rio Muni listed by Cabrera (1929) and Basilio (1962), but these authors did not provide lists of localities or specimens examined.

\section{Methods ANd Materials}

The data presented herein were obtained from specimens collected and observed at the localities shown in Fig. 1. Specimens obtained by me were shot. Anomalurids were observed either with the unaided eye or with $10 \times 50$ Bushnell binoculars. Individuals were watched in the dark with the aid of a 6-volt spotlight. Time when anomalurids were seen was recorded in local time, which was 1 hour earlier than Greenwich Mean Time. Nomenclature of anomalurids used here was taken from Misonne (1968).

In the lists of specimens examined, numbers in parentheses preceding localities correspond to numbers in Fig. 1. Numbers after each locality refer to the number of specimens examined from that locality. Initials identify specimens stored in collections at the British Museum (Natural History) (BMNH), United States National Museum of Natural History (USNM), University of New Mexico (UNM), and Tulane University (TU).

\section{Results AND Discussion}

Misonne (1968) recognized three genera and seven species, including two subfamilies, of African Anomaluridae but Rosevear (1969) listed only six species for West Africa. The anomalurids of Rio Muni and adjacent Cameroon presented herein included one genus and two species of the subfamily Anomalurinae and a single species of the subfamily Idiurinae.

\section{Anomalurus derbianus (Gray)}

This species was recorded from nine localities (Fig. 1). Specimens were examined from six sites and individuals were observed at three additional places. They were found in hollow trees (Irvingia oblonga) in relatively 


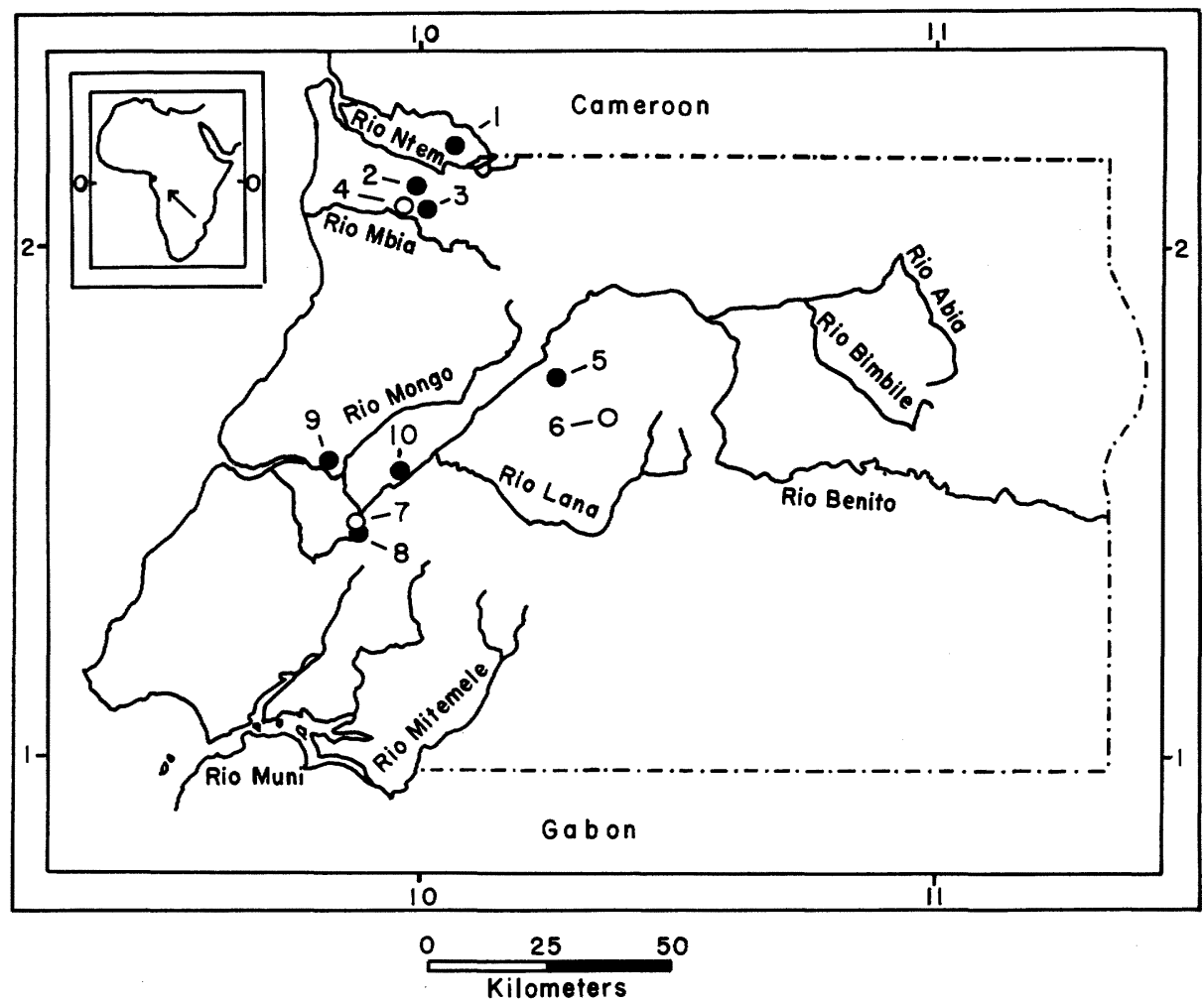

Fig. 1.-Map of Rio Muni showing localities of known occurrence of anomalurids. Dots indicate localities where specimens were obtained and circles represent localities where anomalurids were observed.

undisturbed forests, as well as in trees left standing in areas cleared by man. Hollows utilized by anomalurids ranged from about 0.3 to 2.5 meters in diameter and up to an estimated 40 meters in height. These hollows were open at the top and bottom.

Of the A. derbianus encountered during this study, most were found either at rest during the day in hollow trees or emerging from hollow trees after dusk (Table 1). One was seen apparently foraging shortly after dawn. Another emerged from a hole in a tree at midmorning; this individual was probably disturbed by the observer.

There was considerable variation with regard to the number of A. derbianus found inside each hollow tree (Table 2 ). Of the hollow trees examined carefully during this study, 40 per cent housed none, 20 per cent contained a single animal, 30 per cent contained two, and 10 per cent included three individuals of A. derbianus.

Some variation was apparent with regard to the regular occurrence of $A$. derbianus in the trees examined. For example, anomalurids were seen on 
TABLE 1.-Activities of A. derbianus observed in Rio Muni.

\begin{tabular}{lcll}
\hline \multicolumn{1}{c}{ Date } & Number & Time & \multicolumn{1}{c}{ Activity } \\
\hline 19 October 1967 & 1 & 0745 & Foraging \\
11 November 1967 & 1 & 1035 & Emerging from hole \\
13 December 1967 & 1 & 1845 & Gliding \\
19 January 1968 & 1 & 1855 & Gliding \\
30 January 1968 & 1 & 1906 & Gliding \\
31 January 1968 & 1 & 1905 & Gliding \\
1 February 1968 & 1 & 1904 & Gliding \\
2 February 1968 & 2 & 0840 & At rest in tree \\
2 February 1968 & 1 & 1020 & At rest in tree \\
19 February 1968 & 2 & 0850 & At rest in tree \\
19 March 1968 & 3 & 1315 & At rest in tree \\
27 April 1968 & 1 & 0920 & At rest in tree \\
15 May 1968 & 2 & 1630 & At rest in tree \\
\hline
\end{tabular}

each examination of some trees, but were present only occasionally in other trees. In the late phases of this study, specimens were collected from some sites, but subsequent visits to the same trees revealed the presence of additional animals.

Individuals were observed clinging to the sides of trees at estimated heights of 8 to 25 meters, usually 5 to 10 meters below the tops of the chambers. Most animals were oriented with the head up and the body parallel with the bole of the tree. When several A. derbianus were seen in one tree, they were adjacent to each other. When disturbed, all individuals observed moved to the top of the hollow and either remained just below an opening or fled.

On five occasions, anomalurids emerged from known diurnal resting sites regularly a short time after dusk (Table 1). At one locality, an individual emerged from a tree within 11 minutes of the same time on four evenings, but I do not know if it was the same animal. Individuals departed from near an opening about 25 meters from the ground. On one occasion, an animal emerged from a hole about 10 meters above the ground, ran up the tree to the vicinity of the upper opening, and left the tree. The glides terminated at various places in the low vegetation within about 15 meters from the hollow tree. On one occasion, I saw an individual glide across a road for a distance of about 40 meters. Rosevear (1969) reported glides of about 50 yards for this species. Some information on patterns of glides of anomalurids was presented by Rahm (1969).

In Rio Muni, lactating females were collected in February and May. A male with enlarged testes $(28 \times 10$ millimeters $)$ was obtained in May. Data on reproduction were summarized by Asdell (1964), who suggested that there might be two breeding seasons.

Specimens examined.-(1) Dipikar Island, $10^{\circ} 3^{\prime} \mathrm{E}$ long., $2^{\circ} 12^{\prime} \mathrm{N}$ lat., 2 (TU); (2) Near Ayamiken, $10^{\circ} 1^{\prime} \mathrm{E}$ long., $2^{\circ} 7^{\prime} \mathrm{N}$ lat., 1 (TU); (3) $4 \mathrm{~km} \mathrm{~S}$ Ayamiken, $10^{\circ} 1^{\prime} \mathrm{E}$ long., 
TABLE 2.-Number of A. derbianus in hollow trees examined in Rio Muni.

\begin{tabular}{lccc}
\hline \multicolumn{1}{c}{ Date } & Trees & Animals & Animals/tree \\
\hline 2 February 1968 & 3 & 3 & 1.0 \\
19 February 1968 & 1 & 2 & 2.0 \\
19 March 1968 & 2 & 3 & 1.5 \\
27 April 1968 & 3 & 1 & 0.3 \\
15 May 1968 & 1 & 2 & 2.0 \\
Total & 10 & 11 & 1.1 \\
\hline
\end{tabular}

$2^{\circ} 6^{\prime} \mathrm{N}$ lat., 1 ( TU); (5) $3 \mathrm{~km} \mathrm{~S}$ Niefang, $10^{\circ} 16^{\prime} \mathrm{E}$ long., $1^{\circ} 49^{\prime} \mathrm{N}$ lat., 1 ( $\mathrm{TU}$ ); (8) Bisun, $9^{\circ} 52^{\prime} \mathrm{E}$ long., $1^{\circ} 25^{\prime} \mathrm{N}$ lat., 2 (TU), 1 (UNM); (10) near Benito River, $20 \mathrm{mi}$. from mouth, 4 (BMNH).

Additional records.-(4) Rio Mbia, $9^{\circ} 57^{\prime} \mathrm{E}$ long., $2^{\circ} 5^{\prime} \mathrm{N}$ lat.; (6) Mt. Alen, $10^{\circ} 18^{\prime}$ E long., $1^{\circ} 40^{\prime} \mathrm{N}$ lat.; (7) Mt. Okoro Biko, $9^{\circ} 52^{\prime} \mathrm{E}$ long., $1^{\circ} 28^{\prime} \mathrm{N}$ lat.

\section{Anomalurus beecrofti Fraser}

Specimens were collected at two localities by G. L. Bates in the period 1897 to 1899 (Fig. 1), but I obtained no specimens during this study.

According to Bates (1905), A. beecrofti was located usually in hollow trees during the day, but was seen on the outside of trees in the evening in Rio Muni and south Cameroon. Sanderson (1940) apparently never observed this species in a hollow tree, but noted that $A$. beecrofti inhabited the dense foliage in the upper strata of the forests of northern Cameroon.

Data from contrasting reports on activities of this species were summarized by Rosevear (1969), who concluded that A. beecrofti was nocturnal, usually becoming active at sundown. He reported pregnant animals in June, July, and October.

Specimens examined.-(9) Benito River, 15 mi. from mouth, 1 (BMNH), 2 (USNM); (10) Benito River, 20 mi. from mouth, 2 (BMNH), 1 (USNM).

Idiurus zenkeri Matschie

A single specimen was obtained from extreme southwestern Cameroon near the border of Rio Muni (Fig. 1). Specimens of Idiurus collected by G. L. Bates and deposited in the British Museum (Natural History) include one example each of I. zenkeri and I. macrotis from the Benito River, French Congo (Gabon). In Cameroon, Sanderson (1940) found colonies of up to 100 in hollow trees during the day. No reproductive information was located for any species of Idiurus.

Specimens examined.-(1) Dipikar Island, $10^{\circ} 3^{\prime} \mathrm{E}$ long., $2^{\circ} 12^{\prime} \mathrm{N}$ lat., 1 ( TU ); Benito River, French Congo (not mapped), 1 (BMNH).

\section{REMARKS}

On 19 February 1968, four individuals of I. zenkeri and two of A. derbianus were located in a tree on Dipikar Island; individuals of each species were 
clustered across the chamber from the other. The two A. derbianus and one I. zenkeri were shot. This site was visited again on 19 March 1968 but the tree contained no anomalurids. Coexistence of A. derbianus, A. beecrofti, A. peli, and Idiurus was mentioned by Rosevear (1969). Sanderson (1940) found $I$. zenkeri and I. macrotis in the same hollow tree.

On 19 March 1968, three A. derbianus and four Hipposideros cyclops were found in a hollow tree $4 \mathrm{~km} \mathrm{~S}$ Ayamiken. This locality was visited again on 15 May 1968, when one specimen of A. derbianus and one of $H$. cyclops were shot. On both occasions, the bats roosted 4 to 5 meters above the anomalurids. Bates (1905) obtained Idiurus and H. cyclops in the same hollow tree.

\section{ACKNOWLEDGMENTS}

Specimens in the British Museum (Natural History) were made available to me by Gordon Corbet and John Hill. Frances Miller helped obtain and prepare specimens. Information on Anomaluridae was provided by Henry W. Setzer, who also made helpful suggestions on the manuscript. The map was drawn by Wilma Martin. Financial support of field studies in Rio Muni was provided by the National Geographic Society and the National Institutes of Health (FR00164).

\section{Literature Cited}

Adam, F., L. Bellier, ANd L. W. Robbins. 1970. Deux nouvelles captures d'Idiurus macrotis Miller (Rodentia, Anomaluridae) en Côte d'Ivoire. Mammalia, 34: $716-718$.

AsDell, S. 1964. Patterns of mammalian reproduction. Cornell Univ. Press, Ithaca, New York, 2nd ed., viii +670 pp.

Basirıo, R. 1962. La vida animal en la Guinea española. Instituto de Estudios Africanos Consejo Superior de Investigaciones Científicas, Madrid, $190 \mathrm{pp}$.

Bates, G. 1905. Notes on the mammals of southern Cameroons and the Benito. Proc. Zool. Soc. London, pp. 65-85.

Cabrera, A. 1929. Católogo descriptivo de los mamíferos de la Guinea española. Mem. Real Soc. Española Hist. Nat., 121 pp.

Durrell, G. 1954. The Bafut beagles. Ballantine Books, New York, 191 pp.

McLaughlin, C. 1967. Aplodontoid, sciuroid, geomyoid, castoroid, and anomaluroid rodents. Pp. 210-225, in Recent mammals of the world ( S. Anderson and J. K. Jones, Jr., eds.), Ronald Press Co., New York, viii +453 pp.

Misonne, X. 1968. Rodentia. Pp. 1-55, in Preliminary identification manual for African mammals (J. Meester, ed.), Smithsonian Institution, U. S. Nat. Mus., Washington, D. C.

RAHM, U. 1969. Dokumente über Anomalurus und Idiurus des östlichen Kongo. Z. Säugetierk., 34:75-84.

Rosevear, D. 1969. The rodents of West Africa. British Museum (Natural History), London, xii +604 pp.

SANDERson, I. 1940. The mammals of the north Cameroons forest area. Trans. Zool. Soc. London, 24:623-725.

Walker, E., AND others. 1968. Mammals of the world. The Johns Hopkins Press, Baltimore, 2nd. ed., 2: viii + 647-1500.

Bureau of Sport Fisheries and Wildlife, United States National Museum, Washington, D. C. 20560. Accepted 5 May 1971. 